Удк 616.345-005.1-036.1]-02:618.1-083.98-089

DOI 10.11603/2414-4533.2017.3.8128

(СА. І. РИЛОВ, М. Б. ДАНИЛЮК, М. А. КУБРАК

Запорізький державний медичний університет

\title{
К.лінічний випадок гострої товстокишкової кровотечі в ургентній гінекології
}

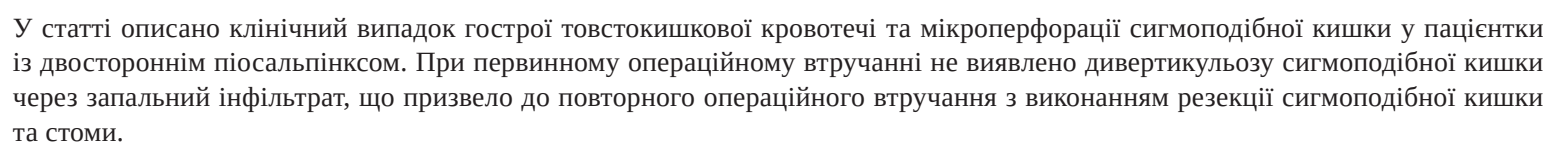

У статті описано клінічний випадок гострої товстокишкової кровотечі та мікроперфорації сигмоподібної кишки у пацієнтки із двостороннім піосальпінксом. При первинному операційному втручанні не виявлено дивертикульозу сигмоподібної кишки через запальний інфільтрат, що призвело до повторного операційного втручання з виконанням резекції сигмоподібної кишки та стоми.

Ключові слова: відеолапароскопія; гінекологія; товстокишкова кровотеча.

Кількість відеолапароскопічних операційних втручань в ургентній хірургії постійно зростає. Даний метод дозволяє покращити якість діагностики, знижує травматичність операції, зменшує кількість післяопераційних ускладнень та скорочує час перебування у стаціонарі [2, 4].

3 початку введення відеолапароскопії у невідкладній гінекології 80 \% усіх операцій були діагностичні. Наданий час це співвідношення змінилося в бік таких операцій, як порушена позаматкова вагітність, розрив, перекрут кісти, апоплексія $[1,3]$.

Однак широке використання вищеперерахованих операцій супроводжується появою характерних помилок та ускладнень.

Опис клінічного випадку. Пацієнтка Б., 38 років, госпіталізована в перше хірургічне відділення КУ "Міська клінічна лікарня швидкої та невідкладної медичної допомоги м. Запоріжжя" 15.06.2017 р. зі скаргами на виражені переймоподібний біль у мезогастральній та гіпогастральній ділянках, здуття живота, нудоту, блювання, підвищення температури тіла до $38{ }^{\circ} \mathrm{C}$. Хворіє протягом доби, доставлена до лікарні в ургентному порядку.

При огляді хворої стан середньої тяжкості, зумовлений інтоксикацією та больовим синдромом. При локальному огляді: живіт піддутий, пальпаторно визначається болючість в мезогастральній, гіпогастральній ділянках, там же позитивні перитонеальні симптоми. Перистальтика вислуховується, в'яла.

У приймальному відділенні проведено додаткові методи обстеження: ультразвукове сканування органів малого таза: ехоознаки об'ємного утворення малого таза, в позадуматковому просторі зліва візуалізується осумкований утвір, неоднорідної структури, розмірами 80х60х65 мм, найі- мовірніше - інфільтрат, гідропельвіоперитонеум (до 150 мл).

Загальний аналіз корові (15.06.17р.): еритроцити - 4,50 Т/л, гемоглобін - 149 г/л, КП - 0,9, лейкоцити - 15,8 Г/л, ШОЕ - 42 мм/год. Лейкоцитарна формула: паличкоядерні - $12 \%$, сегментоядерні - 66 \%, лімфоцити - $16 \%$, моноцити $6 \%$.

15.06.2017 р. В ургентному порядку пацієнтці виконано операційне втручання: відеолапароскопія під внутрішньовенною анестезією із штучною вентиляцією легень.

Інтраопераційно: в малому тазі та правій здухвинній ділянці до 200 мл гнійного випоту, при огляді органів малого таза матка не збільшена у розміріх, яєчники також не змінені. Маткові труби значно збільшені в розмірі, їх стінки набряклі, гіперемійовані, із труб гнійне виділення. Враховуючи дані ревізії проведено видалення маткових труб із двох сторін. Черевна порожнина промита розчинами антисептиків, санована електровідсмоктувачем. Про огляді шлунок, дванадцятипала кишка, печінка, селезінка, жовчний міхур без видимої патології. Петлі тонкого кишечника роздуті, перистальтика ослаблена - розцінено як парез. При огляді товстого кишечника виявлені інфільтративно-запальні зміни в ділянці сигмоподібної кишки, стінка її потовщена, гіперемійована - розцінено як запальні зміни внаслідок пельвіоперитоніту. Операцію закінчено дренуванням черевної порожнини та малого таза.

У післяопераційному періоді хворій проводили консервативну терапію із призначенням антибіотиків широкого спектра дії (цефалоспорини III покоління), метронідазол, інфузійна терапія, стимуляція перистальтики, знеболювальна терапія та промивання черевної порожнини і малого таза розчином діоксидину $1 \%$. 
Стан пацієнтки був із позитивною динамікою, функція перистальтики відновилася на третю добу післяопераційного періоду, по дренажам гнійного випоту не було. Спостерігались позитивні зміни і у загальному аналізі крові (від 20.06.17р.): лейкоцити - 9,6 Г/л, паличкоядерні - 7 \%. Температурна реакція знизилась до $36,8-37,2^{\circ} \mathrm{C}$.

Гістологічний висновок № 15154 - 15161 (від 26.06.17р.): двосторонній гнійний сальпінгіт.

Ультразвукове сканування органів малого таза та органів черевної порожнини (від 19.06.17 р. та 26.06.17р.): ехокартина стану після операційного втручання, хронічний панкреатит.

26.06.2017 р. у пацієнтки 3'явилися випорожнення $з$ домішками свіжої крові у об'ємі до 200 мл. Гемодинаміка пацієнтки стабільна, артеріальний тиск 120/80 мм рт. ст., пульс 96 уд./хв, по дренажами серозне виділення - до 50 мл, при огляді стан стабільний, живіт не здутий, перистальтика вислуховується, спостерігається незначна болючість у ділянці післяопераційного рубця, перитонеальні симптоми відсутні. Враховуючи клінічні дані нами було призначено консервативну гемостатичну терапію та інфузію кристалоїдних і колоїдних розчинів. При огляді в динаміці - даних за продовження кровотечі немає. Загальний аналіз крові (від 26.06.2017р.): гемоглобін - 112 г/л, еритроцити - 3,69 Т/л, КП - 0,9, лейкоцити - 10,6 Г/л, ШОЕ - 58 мм/год, формула: паличкоядерні $10 \%$, сегментоядерні - $68 \%$, лімфоцити - 18, моноцити - 4.

Хворій було продовжено консервативну гемостатичну терапію та проводилась підготовка для обстеження - колоноскопія.

29.06.2017 р. виник рецидив товстокишкової кровотечі у об'ємі до 500 мл зі зниженням гемодинаміки: артеріальний тиск 100/60 мм рт. ст., пульс 120 уд./хв. Показники крові: гемоглобін 101 г/л, еритроцити - 3,48 Т/л, гематокрит - 0,30, об’єм циркулюючої крові - 6,34 л, дефіцит - 366 мл.

Враховуючи рецидив кровотечі пацієнтка в ургентному порядку прооперована. Під загальною анестезією із штучною вентиляцією легень вико-

\section{СПИСОК ЛІТЕРАТУРИ}

1. Грубник Ю. В. Показания и эффективность использования малоинвазивных операций у больных с закрытой травмой брюшной полости / Ю. В. Грубник [ и др.] // Харківська хірургічна школа. - 2014. - № 1 (65). - С. 101 - 104.

2. Матвійчук Б. О. Роль та значення відеолапарскопії в діагностично-лікувальному алгоритмі хворих з атиповим перебігом гострого апендициту / Б. О. Матвійчук, А. Д. Квіт // Український журнал хірургії. - 2014. - № 1 (24). - С. 58 - 60. нано операційне втручання: нижньо-серединна лапаротомії. Інтраопераційно виявлено інфільтративно запальні зміни в ділянці нижньої третини сигмоподібної кишки. Далі при детальному огляді виявлено дивертикули в ділянці середньої та нижньої третини із запальними змінами та мікроперфоративним отвором у ділянці дивертикула по брижовому краю нижньої третини сигмоподібної кишки. В малому тазі до 50 мл серозного випоту. Враховуючи запальні зміни в ділянці кишки та високий ризик неспроможності швів при первинному анастомозі, пацієнтці проведена резекція сигмоподібної кишки із дивертикулами та виведенням одностовбурної сигмостоми. Санування та повторне дренування черевною порожнини і малого таза. При огляді решти відділів товстого кишечника - дивертикульозу не виявлено.

Макропрепарат: ділянка сигмоподібної кишки, стінка якої потовщена та гіперемійована. Виявлено множинні дивертикули та мікроперфорація одного по брижовому краю. Кишка заповнена свіжою кров’ю та згустки в дивертикулах.

Гістологічний висновок № 16327 - 16338 (від 09.07.2017 р.): дивертикульоз сигмоподібної кишки з перфорацією дивертикула. Товстокишкова кровотеча.

У післяопераційному періоді пацієнтці проводили антибіотикотерапію зі зміною групи антибіотиків, знеболювання, інфузійну терапію.

У післяопераційному періоді рецидивів кровотечі не було. Пацієнтку виписали зі стаціонару 10.07.2017 р. у задовільному стані з функціонуючою сигмостомою. Рекомендовано реконструктивний етап через 4-6 місяців після операційного втручання.

Незважаючи на високу ефективність лапароскопічних оперативних втручань та можливість широкої ревізії, слід зазначити, що при відеолапароскопічних маніпуляціях в тканинах із інфільтративно-запальними змінами обмежений детальний та пальпаторне обстеження, що може призвети до діагностичних помилок і пропускання супутньої патології.

3. Чемоданов Е. Б. Выбор тактики хирургического лечения у больных спаечной болезни брюшной полости / Е. Б. Чемоданов, Е. В. Заевская // Труды Крымского гос. мед. универ. 2008. - T. 144, № 4.1. - С. 262 - 265.

4. Sauerland S. Laparoscopic versus open surgery for suspected appendicitis / S. Sauerland, T. Jaschinski, E. A. Neugebauer // Cochrane Database Syst. Rev. - 2010. - № 10. - P 140. 


\title{
ПОВІДОМЛЕННЯ
}

\section{REFERENCES}

1. Grubnik, Yu.V. (2014). Pokazaniya i effektivnost ispolzovaniya maloinvazivnykh operatsiy u bolnykh s zakrytoy travmoy bryushnoy polosti [Indications and efficacy of the use of minimally invasive surgery in patients with closed abdominal trauma]. Kharkivska khirurhichna shkola - Kharkiv Surgical School, 1 (65), 101-104 [in Ukrainian].

2. Matviichuk, B.O., \& Kvit, A.D. (2014). Rol ta znachennia videolaparoskopii v diahnostychno-likuvalnomu alhorytmi khvorykh $\mathrm{z}$ atypovym perebihom hostroho apendytsytu [Videolaparoscopy role and importance in diagnostic - therapeutic algorithm of patients with atypical course of acute appendicitis]. Ukrainskyi zhurnal khirurhii -
Ukrainian Journal of Surgery, 1 (24), 58-60 [in Ukrainian].

3. Chemodanov, E.B., \& Zaevskaya, E.V. (2008). Vybor taktiki khirurgicheskogo lecheniya u bolnykh spaechnoy boleznyu bryushnoy polosti [The choice of tactics of surgical treatment in patients with abdominal adhesive disease]. Trudy Krymskogo gosudarstvennogo melitsinskogo universiteta - Works of the Crimean State Medical University, 144 (4.1), 262-265 [in Ukrainian].

4. Sauerland, S., Jaschinski, T., \& Neugebauer, E.A. (2010). Laparoscopic versus open surgery for suspected appendicitis. Cochrane Database Syst. Rev., (10), 140 [in Russian].

Отримано 04.07.2017

\section{A. I. RYLOV, M. B. DANYLYUK, M. A. KUBRAK}

Zaporizhzhia State Medical University

\section{CLINICAL CASES OF ACUTE COLONIC BLEEDING IN URGENT GYNECOLOGY}

This article describes the clinical case of acute colonic bleeding and microperforation of the sigmoid colon in a patient with bilateral pyosalpinx. At primary operative intervention, diverticulosis of the vagmoid colon was not detected through an inflammatory infiltrate, which led to repeated surgical intervention with resection of the sigmoid colon and stoma.

Key words: video laparoscopy; gynecology; colonic bleeding.

\author{
А. И. РЫЛОВ, М. Б. ДАНИЛЮК, М. А. КУБРАК
}

Запорожский государственный медицинский университет

\section{КЛИНИЧЕСКИЙ С.ЛУЧЙ ОСТРОГО ТОЛСТОКИНЕЧНОГО КРОВОТЕЧЕНИЯ В УРГЕНТНОЙ ГИНЕКОЛОГИИ}

\begin{abstract}
В статье описано клинический случай острого толстокишечного кровотечения и микроперфорации сигмовидной кишки у пациентки с двухсторонним пиосальпинксом. При первичном оперативном вмешательстве не было обнаружено дивертикулеза сигмовидной кишки через воспалительный инфильтрат, что привело к повторному оперативному вмешательству с выполнением резекции сигмовидной кишки и стомы.
\end{abstract}

Ключевые слова: видеолапароскопия; гинекология; толстокишечное кровотечение. 